Terr. Atmos. Ocean. Sci., Vol. 18, No. 4, 739-755, October 2007

\title{
Biomarker Distributions as Maturity Indicators in Coals, Coaly Shales, and Shales From Taiwan
}

\author{
Jun-Chin Shen ${ }^{1,2, *}$ and Wuu-Liang Huang ${ }^{2}$ \\ (Manuscript received 22 September 2006, in final form 12 March 2007)
}

\begin{abstract}
The distribution of hopanoids and alkanes in bitumen extracts of coals, coaly shales, and shales from northwestern Taiwan has been measured to assess the maturity of potential petroleum source rocks in the studied area. The $\mathbf{C}_{31}$ homohopane isomers of the studied coals and coaly shales attain equilibrium at maturity corresponding to $0.6 \%$ Ro measured in coals or $0.65 \%$ Ro in adjacent shales. A proposed parameter using hopanoid ratios reveals a more consistent trend and approaches a steady value at maturity similar to the $C_{31}$ homohopane isomer ratio. The results show that the onset of the main phase of petroleum generation in northwestern Taiwan takes place at maturity corresponding to VR of $0.6 \%$ Ro measured in coals or coaly shales and probably higher VR in shales. The distribution of pristane, phytane $n-C_{17}$ and $n-C_{18}$ confirms the validity of the conventional maturity indicators if the samples are from the same source, but shows depositionalor organic-source controls. The source influence on the phytane $/ \mathbf{n}-\mathrm{C}_{18}$ ratio appears to be larger than that on the pristane $/ n-C_{17}$ ratio. The phytane $/ n-C_{18}$ ratio is also less sensitive to maturity than that of the pristane $/ n-C_{17}$ ratio. The pristane/phytane ratios in the studied coals and coaly shales, in contrast to the pristane $/ \mathbf{n}-\mathrm{C}_{17}$ ratio, continue to decrease to maturities beyond the oil window up to $1.5 \%$ Ro and therefore may be applicable to high maturity sources.
\end{abstract}

(Key words: Biomarker, Pristane/phytane, Vitrinite, Maturity, Coal, Shale, Taiwan)

\footnotetext{
${ }^{1}$ EDRI, Chinese Petroleum Corp., Miaoli, Taiwan, ROC

2 Department of Geosciences, National Taiwan University, Taipei, Taiwan, ROC

* Corresponding author address: Dr. Jun-Chin Shen, EDRI, Chinese Petroleum Corp., Miaoli, Taiwan, ROC; E-mail: 048470@cpc.com.tw doi: 10.3319/TAO.2007.18.4.739(TT)
} 


\section{INTRODUCTION}

The sources and maturity of gas, condensate or light oil occurring in northwestern Taiwan have been of major research as well as exploration interest. Vitrinite reflectance (VR) has been the most commonly used maturity indicator for the rocks and coals of terrestrial sources in this province (Lu 1980; Kuo 1997; Shen and Kuo 1991). A previous study, however, reveals a discrepancy between the VR measured in organic matter from a variety of shales and adjacent coal seams (Bostick and Foster 1975). It has been found in our study area (Kuo et al. 1987; Shen and Kuo 1991) that the average VR measured from the dispersed type-III organic matter in shales is slightly higher $(0.04 \%)$ than those from adjacent humic coals (Fig. 1). A negative correlation between VR and the hydrogen index (HI) has been found for organic matter in shales of similar thermal maturity but not for coals (Fig 1). The difference in VR between coals and shales should be larger (up to $0.15 \%$ ) after correction for suppression using their hydrogen index (Lo 1988), leading to some uncertainty in evaluating the maturities of the source rocks in this area. Alternatively, the thermal maturities of source rocks may be evaluated using independent parameters such as biomarkers. Some of these parameters and their correla-

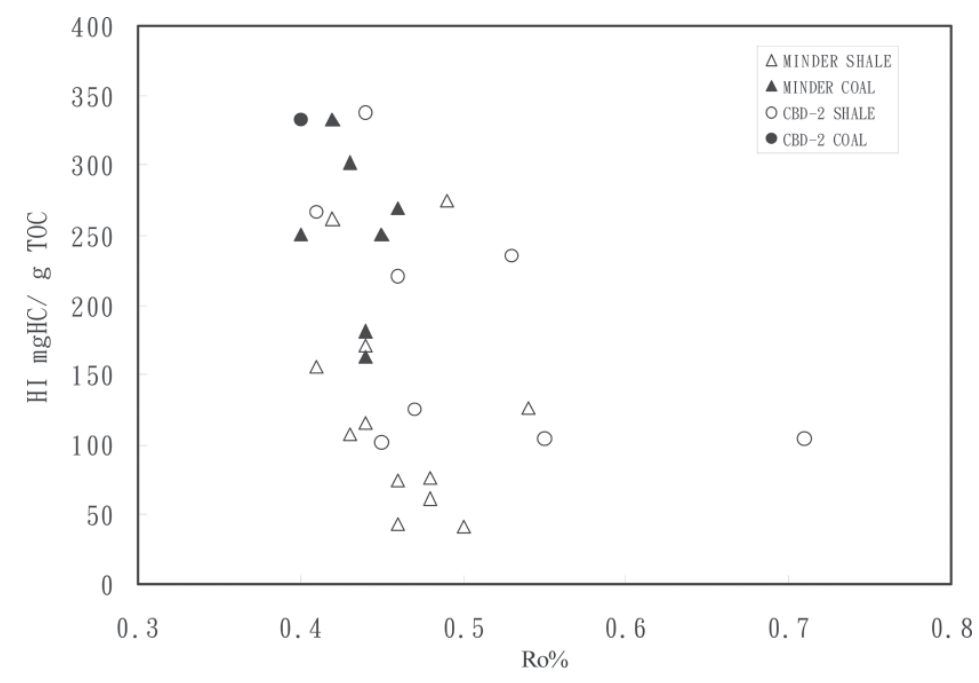

Fig. 1. Hydrogen index (HI) and vitrinite reflectance of coals and shales of the samples from northwestern Taiwan (Kuo et al. 1987; Shen and Kuo 1991); the solid and open symbols indicate, respectively, coals and adjacent shales; triangles are samples from Minder area, Miaoli; circles are samples from offshore wells (CBD-2), northwestern Taiwan. The vitrinite reflectances measured from the dispersed type-III organic matter in shales are slightly higher than those from adjacent humic coals, and there is a negative correlation between HI and VR for shale samples (open triangles). Note that the samples presented in this figure are not the samples used in this study. 
tion to organic maturity have been well studied from other samples worldwide, which can be used to calibrate the observed vitrinite reflectance of organic matter from northwestern Taiwan.

Whilst biomarker molecules of oils from Taiwan have been previously analyzed (Wu et al. 1986; Chou et al. 1987; Oung 1989), only a few bitumen extracts from coals and shales in this area have been examined (Oung et al. 2003). This study focuses on analyzing biomarker molecules in bitumen extracts from shales, coaly shale, and coals in order to provide independent maturity indicators other than VR. For estimating the maturity of bitumen, we apply conventional biomarker maturity parameters based on hopanoids and branched alkanes (van Graas et al. 1981; Goossens et al. 1988; Fabianska et al. 2003). The branched alkanes, including pristane, $\mathrm{n}-\mathrm{C}_{17}$, phytane, and $\mathrm{n}-\mathrm{C}_{18}$, are of interest because they are present in significant amounts in condensate or light oil to which most discovered oils from northwestern Taiwan belong and from which few other maturity indicators are available.

\section{EXPERIMENTAL METHODS}

\subsection{Characterization of Samples}

Twenty-eight humic coals or coaly shales with maturity ranging from immature to mature covering the entire oil window were selected for this study (Table 1). Coal and coaly shale samples, except for sample No. 1 in Table 1, were mainly collected from outcropped coal measures of the middle late Miocene and early Miocene formation in various locations in the Taihsi-Taichung basin of northwestern Taiwan (Fig 2). A geological column indicating relevant formations of the studied samples is also shown in Fig. 2. The sample locations and stratigraphic ages (Fig. 2) are presented in Table 1. The occurrences and characteristics of coals and coaly shales are essentially similar, except that coaly shales contain higher $(>67 \%)$ minerals and clay matrix. The additional coal sample, sample No. 1, was collected from a conventional core from an offshore well.

\subsection{Analytical Procedures}

Whole rock samples were cleaned with special attention to remove weathered surfaces on the samples and then crushed to a fine powder using an agate motor and pestle. The basic geochemical information of the powdered samples was obtained using ROCK-EVAL 2 (Peters 1986) for calculating the hydrogen index (HI; Fig. 1) and using a carbon/sulfur analyzer for TOC and sulfur contents. The isolated organic matter from the samples was microscopically analyzed for maceral types and their maturity levels.

Analyses in this study include petrography observations of coal macerals, measurements and gas chromatography-mass spectrometry (GC-MS) analyses. The petrography and VR measurement were performed on polished sections using a Zeiss Airplane microscope. Types of macerals were distinguished using standard coal petrography technique with the assistance of fluorescence while the VR was measured mostly from telecollinite under the x 20 objective lens with oil immersion. The VR was reported in terms of Ro (\%). The reflectance was measured using a photomultiplier which was calibrated against the Zeiss reflectance standard (Ro $=0.5 \%$ 


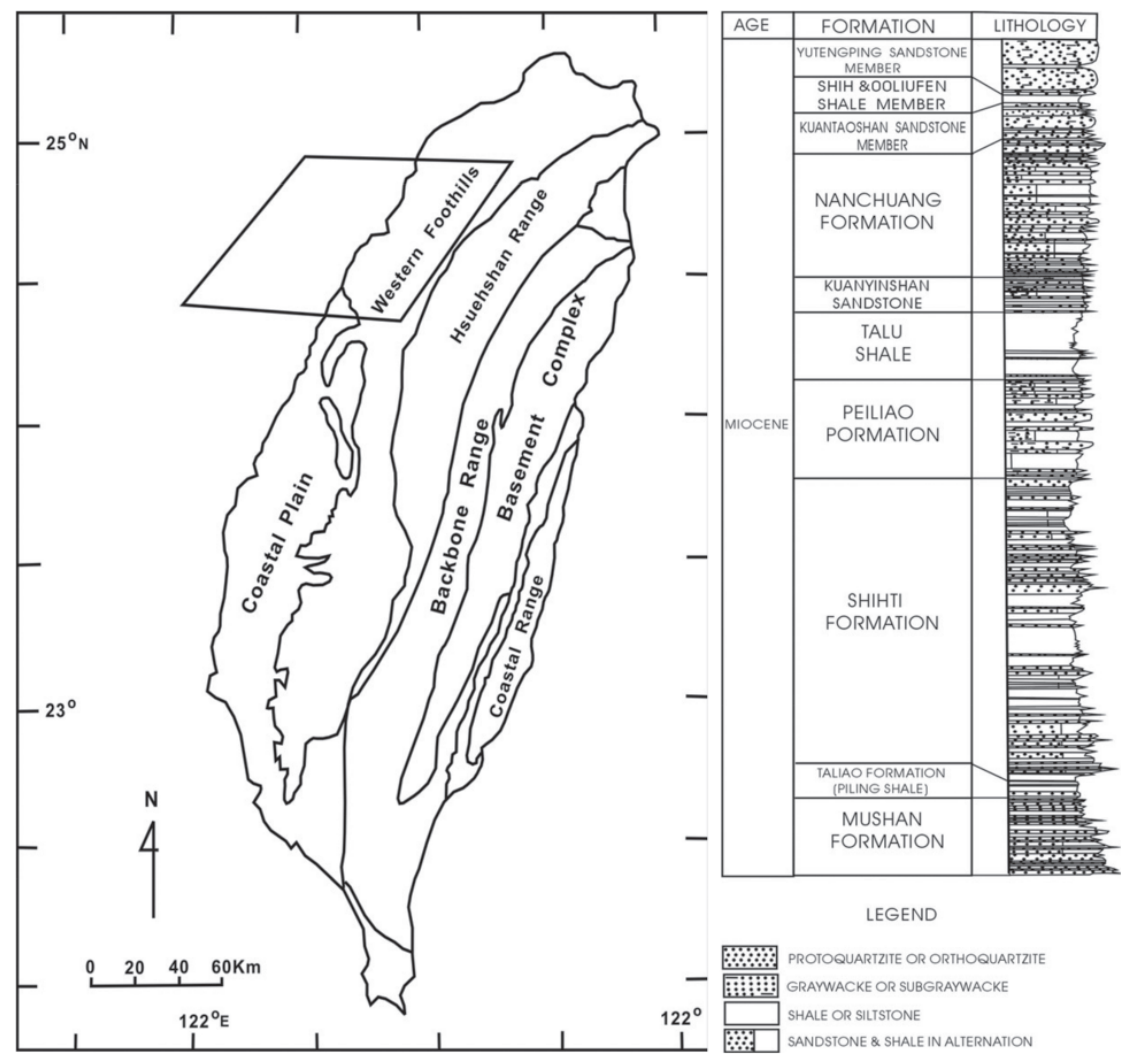

Fig. 2. The location map indicating the study area. Most of the coals, coaly shales and shales were collected from outcropped Miocene formations in the foothills of the Taichung basin and some from offshore wells (CBD-2), northwestern Taiwan (the area indicated by rhomb shape). The geological column for the relevant stratigraphic formations in this area is also presented.

and $1.7 \%)$. The reported reflectance was averaged from about 100 measurements of each sample with standard deviation around $\pm 0.015 \%$ Ro.

Extractable organic matter (EOM) was obtained by solvent extraction (273:27 dichlomethane : methanol) of powdered samples without acid pretreatment. The EOM was separated into saturate, aromatic fractions and resin plus asphaltene respectively, using n-hexane and a mixed solution of $25: 15 n$-hexane : dichlomethane according to standard high pressure liquid chromatography (HPLC) techniques. For preventing the loss of light hydrocarbons, the evaporation of solvent was performed without a vacuum or nitrogen stripping process. The saturate fractions were characterized by gas-chromatography (GC) and GC-MS analyses. GC-MS analyses were performed with VG platform II coupled to a Carlo-Erba 8000 gas chromatograph. 
A Chrompack WCOT ( $60 \mathrm{~m}, \varphi 0.25 \mathrm{~mm}$, outer diameter $0.32 \mathrm{~mm}$, film thickness $0.25 \mu \mathrm{m}$, GP-SIL 5 CB, Low Bleed/MS DF $=0.25$ ) fused silica capillary column was used. The temperature program for analyzing saturate was $60-280^{\circ} \mathrm{C}$ at $4{ }^{\circ} \mathrm{C} \min ^{-1}, 280-300^{\circ} \mathrm{C}$ at $2^{\circ} \mathrm{C} \mathrm{min}^{-1}$, and isothermally held at $300^{\circ} \mathrm{C}$ for $40 \mathrm{~min}$.

\section{RESULTS AND DISCUSSIONS}

\subsection{Hopanoids}

Hopanoids in extracts of coals and coaly shales have been analyzed with special focus on hopane $\left[\mathrm{C}_{30} 17 \alpha(\mathrm{H})\right.$-hopane], norhopane [ $\mathrm{C}_{29} 17 \alpha(\mathrm{H})$-hopane], 22S $\mathrm{C}_{31} 17 \alpha(\mathrm{H})$-hopane, 22R $\mathrm{C}_{31} 17 \alpha(\mathrm{H})$-hopane, moretane $\left(\mathrm{C}_{30}\right)$, normoretane $\left(\mathrm{C}_{29}\right), 18 \alpha(\mathrm{H})$-trisnorhopane $(\mathrm{Ts})$, and $17 \alpha(\mathrm{H})$ trisnorhopane (Tm). The correlations of several previously proposed biomarker maturity indices (Mackenzie et al. 1980; Seifert and Moldowan 1980) and other hapanoids isomer ratios with VR measured from the samples (Table 1) have been examined to test their sensitivity and applicability in the studied area.

The ratios of normoretane to moretane reveal a rough trend which shows a significant decrease in ratio from 3.0 to 0.6 with increasing VR from $0.35 \%$ to $0.6 \%$ Ro and then the ratio approaches a steady state near 0.5 at higher maturity up to $0.92 \%$ Ro (Fig. 3). The unusually low ratio $(0.41)$ at $0.92 \%$ Ro is probably attributable to the special thermal history of the sample, which was thermally matured by volcanic activity (Kuo 1997). The ratio has not been used as a maturity parameter because of probable environmental dependence. The observed trend may be mere coincidence and requires further investigation using samples from a variety of sources.

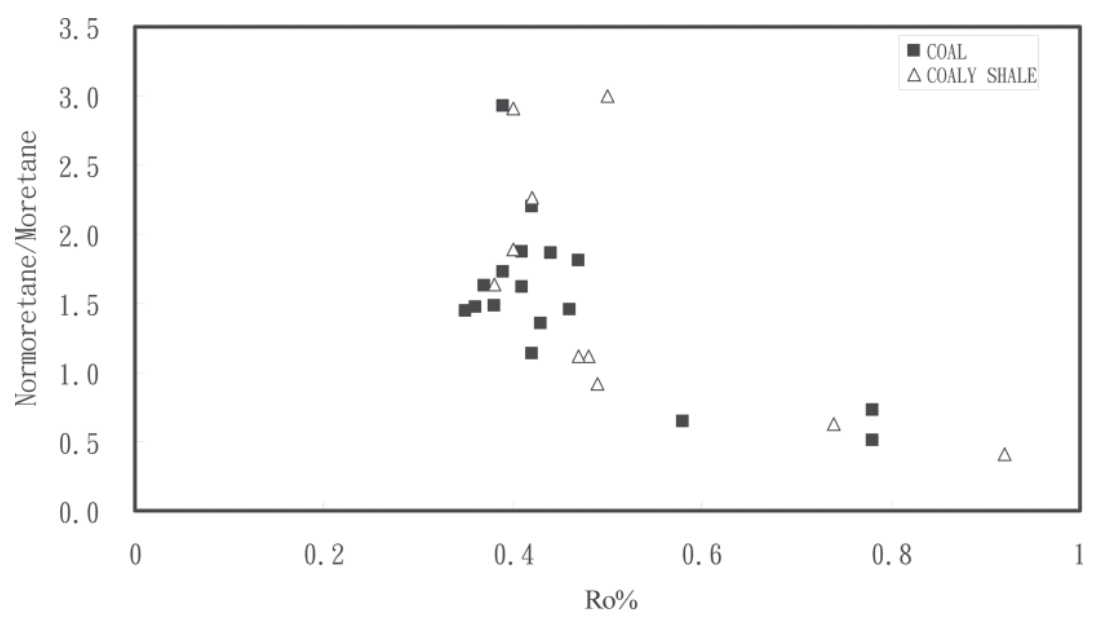

Fig. 3. The variation of ratios of normoretane to moretane in coals and coaly shales as a function of vitrinite reflectance measured for each sample. 
The moretane/hopane ratios show a similar trend ranging from 0.55 to 0.12 as the vitrinite maturity increases from $0.35 \%$ to $0.78 \%$ Ro, but with a wider scattering (Fig. 4). The moretane/ hopane ratios are consistent with the previously reported ratios in bitumen extract that range from 0.8 in immature source rocks to 0.15 in mature source rocks, and 0.05 in highly mature rocks (Peters and Moldowan 1993); these ratios are slightly higher than those of most crude oils (about 0.1 to 0.3 for Tertiary oils and less than 0.1 for older oils; Grantham 1986). The wide scattering of data for these ratios in Fig. 4, which has also been previously reported (Goodarzi et al. 1989), suggests that ratios are partly dependent on source inputs or depositional environments. The initial moretane/hopane ratios of samples from different depositional environments may vary from 0.5 to 1.0 or more (Waples and Machihara 1991).

The normoretane to norhopane ratios decrease with increasing maturity from 0.8 at $0.4 \%$ to 0.1 at $0.78 \%$ Ro, except for one sample with abnormally high ratio at $0.92 \%$ Ro (Fig. 5). The hopane to norhopane ratio, which is not considered a maturity parameter, ranges mostly between 1.75 to 0.5 at maturity from $0.32 \%$ to $0.75 \%$ Ro except for one case at high maturity. This ratio for low mature coals and coaly shales is lower than those (around 2.0) published for very immature organic matter found mostly in silicate-rich source rocks but close to those for carbonate- and evaporite-rich source rocks (Waples and Machihara 1991). An unusually high ratio of 2.92 for a sample at higher maturity $(\mathrm{Ro}=0.92 \%)$, is probably caused by a high heating rate during sample maturation (Bishop and Abbott 1993; Farrimond et al. 1996).

$\mathrm{Ts} /(\mathrm{Ts}+\mathrm{Tm})$ ratios show significant scattering with VR but show a rough trend which increases from 0 to 0.5 with increasing maturity up to about $0.92 \%$ Ro. The scattering of the Ts / $(\mathrm{Ts}+\mathrm{Tm})$ is not unexpected since the ratio also varies with environments (Seifert and Moldowan 1978; Rullkotter and Marzi 1988). Ts is usually very low or in non-detectable amounts, in particular, in coal samples. Ts $/(\mathrm{Ts}+\mathrm{Tm})$ ratios have not shown any correlation

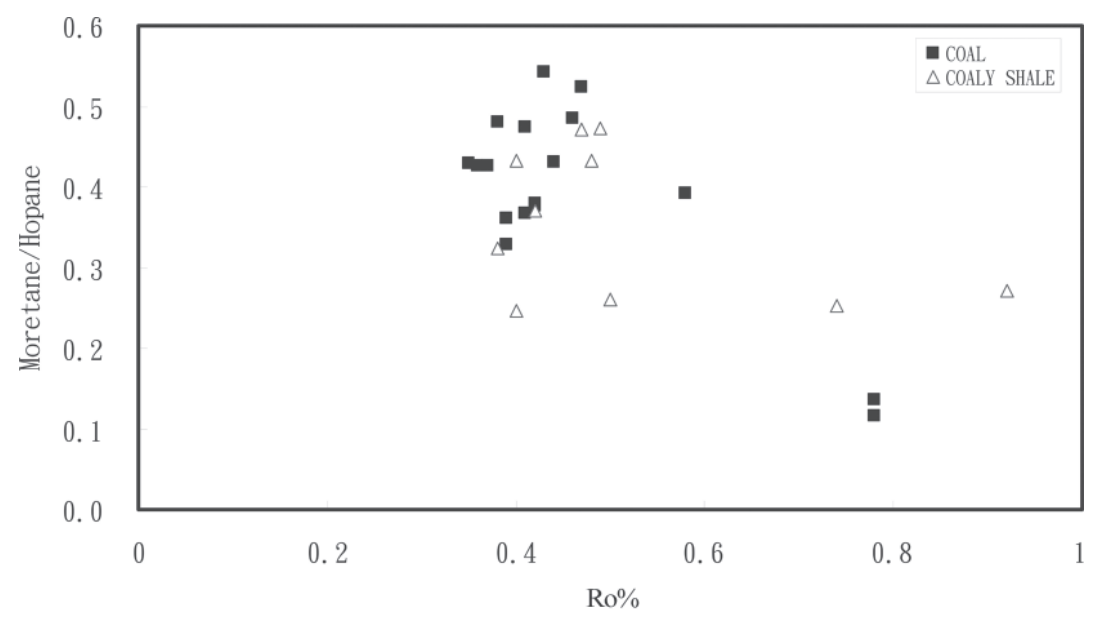

Fig. 4. The variation of ratios of moretane/hopane in coals and coaly shales as a function of vitrinite reflectance measured for each sample. 


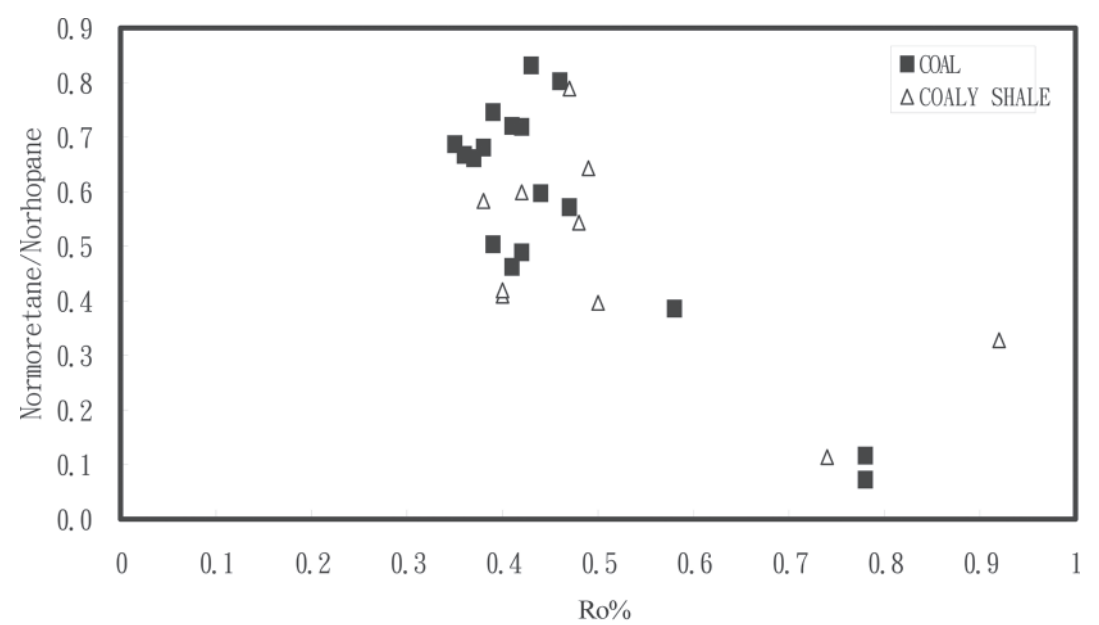

Fig. 5. The normoretane to norhopane ratios decrease with maturity from 0.85 at maturity around $0.4 \%$ to 0.1 at $0.78 \%$ Ro.

with total carbon or host rock composition (mineral matrix), indicating that clays or minerals do not influence the transformation process.

The $22 \mathrm{~S} /(22 \mathrm{~S}+22 \mathrm{R})$ epimer ratios of $\mathrm{C}_{31} 17 \alpha(\mathrm{H})$-hopane show scattering but clustering within a small range below 0.28 as VR maturity varies from $0.35 \%$ to $0.5 \%$ Ro. The ratios increase abruptly to 0.6 as maturity increases from $0.5 \%$ to $0.58 \%$ Ro and remain invariant as maturity increases up to $0.8 \%$ Ro (Fig. 6). The presence of a gap of the epimer ratios between 0.28 to 0.6 in Fig. 6 may be attributed to abnormally high abundance of $\mathrm{C}_{31} 22 \mathrm{R}$ commonly found in coals, which tends to risk the application of the parameter in the study of coals. The observed, steady-state value close to 0.6 is consistent with most prior observations that the isomerization of $\mathrm{C}_{31}$ homohopane commonly equilibrates at a ratio around 0.58 to 0.62 at $\mathrm{Ro}>0.6 \%$ (Peters and Moldowan 1993).

It is believed that the approach to equilibrium of $\mathrm{C}_{31}$-hopane $22 \mathrm{~S} /(22 \mathrm{~S}+22 \mathrm{R})$ ratios in the range of 0.5 to 0.54 may indicate the onset of oil generation while the attainment of equilibrium in the range of 0.57 to 0.62 indicates that the main phase of oil generation has been reached or surpassed (Peters and Moldowan 1993). Our observation for coals and coal shales confirms that the equilibrium between the hopanoid isomers which is closely related to the main phase of petroleum generation occurs at VR around $0.6 \%$ or higher. It is interesting to note that the normoretane to moretane ratio (Fig. 3) for our coals and coal shales also reach a steady-state parameter value at VR near $0.6 \%$ or higher.

Our data also reveal an unusually low $\mathrm{C}_{31}$-hopane $22 \mathrm{~S} /(22 \mathrm{~S}+22 \mathrm{R})$ ratio of 0.38 for a sample at elevated maturity $(\mathrm{Ro}=0.92 \%)$. The deviation of the ratio from the equilibrium to lower values is attributed to a high heating rate during maturation (Lu et al. 1989; Abbott et al. 1990; Peters et al. 1990; Raymond and Murchison 1992; Bishop and Abbott 1993; Requejo 


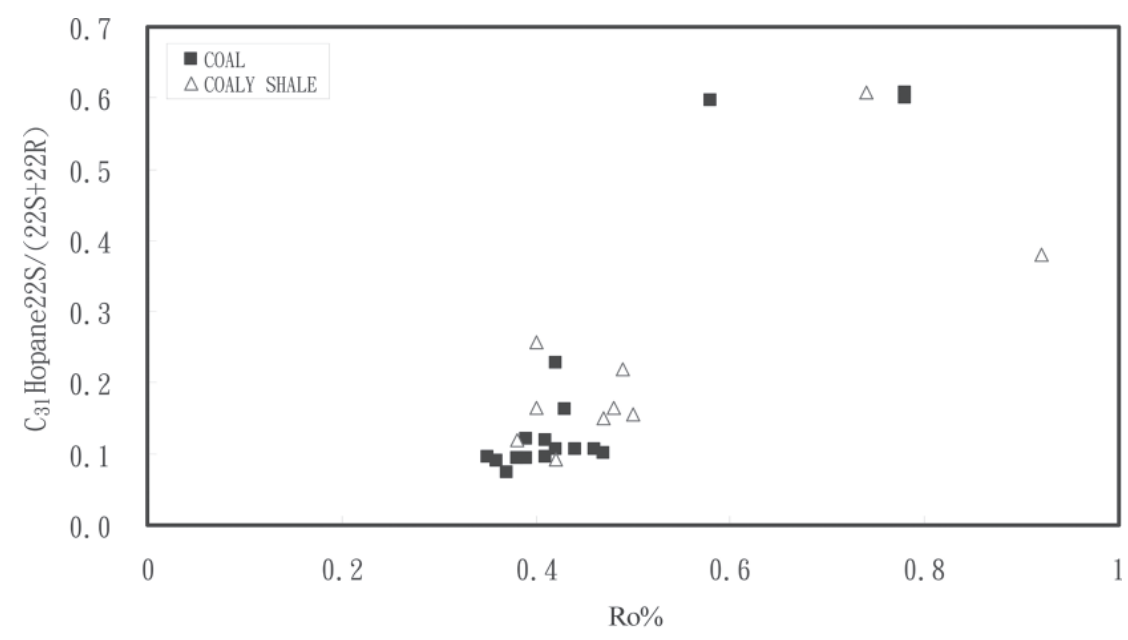

Fig. 6. The variation of $22 \mathrm{~S} /(22 \mathrm{~S}+22 \mathrm{R})$ epimer ratios of $\mathrm{C}_{31} 17 \alpha(\mathrm{H})$-hopane in coals and coaly shales as a function of vitrinite reflectance measured for each sample. Note a gap between 0.28 to 0.6 of the parameter ratio.

1994; Farrimond et al. 1996). The proximity of this special sample to the Tatun volcanic area (Kuo 1997) is consistent with this interpretation.

These conventional maturity indices have been improved by three proposed parameters defined according to four compounds $\mathrm{C}_{31}-22 \mathrm{~S}, \mathrm{C}_{31}$-22R homohopanes and $\mathrm{C}_{29}, \mathrm{C}_{30}$ moretanes (Fig. 7), including (normoretane/moretane) / [ $\left.\mathrm{C}_{31} 22 \mathrm{~S} /(22 \mathrm{~S}+22 \mathrm{R})\right]$, (normoretane/norhopane) $/\left[\mathrm{C}_{31} 22 \mathrm{~S} /(22 \mathrm{~S}+22 \mathrm{R})\right]$, (moretane/hopane) / [ $\left.\mathrm{C}_{31} 22 \mathrm{~S} /(22 \mathrm{~S}+22 \mathrm{R})\right]$, as shown in Fig. 7. Similar to the conventional $\mathrm{C}_{31}$ homohopane index, the parameter ratios approach an equilibrium level at a VR of about $0.6 \%$. While requiring further study, these proposed parameters generate a more spread trend and show a progressive change of the index values with increasing VR from 0.35 to 0.55 before reaching steady-state. These proposed parameters involve trial-and-error using limited data volume. It may be confirmed or improved as more data are available either from the sample area or from other sources.

The study of hopanoid maturity indices provides an assessment of the VR maturity indicator in the studied area, where the production index (PI) and other maturity indicators measured from coals and shales provide little information for accurate definition of the onset of petroleum generation. Measurements of VR for a variety of rocks from northwestern Taiwan (Lu 1980; Shen and Kuo 1991; Kuo 1997) have revealed that most coals and coaly shales have VR values consistently lower than those from the adjacent shales by $0.05 \%$ Ro (Fig. 1). The results also show a negative correlation between Ro (\%) and the hydrogen index (HI) for shale samples with similar maturities, but a similar correlation has not been found for coal samples. The difference in Ro (\%) between the coals and shales may be even larger (up to $0.15 \%$ ) if suppression of Ro $(\%)$ of the shales is corrected for HI. This discrepancy has led to uncertainties in 
determining the onset of petroleum generation in this area. The higher VR measured for the shales than that for the coals and coaly shales may be attributed to more oxic environments during deposition of the shales. However, the difference may be reduced if no correction, or a 'reversed correction' for 'VR suppression', is made for the high HI shales. The hopanoid indices, therefore, provide important evidence for the threshold of petroleum generation at a maturity corresponding to $0.6 \%$ Ro measured for the coals or coaly shales. For the shale, however, we need hopanoid data to conclude that the main phase of petroleum generation corresponds to the maturity of a slightly higher VR in shales.

\subsection{Alkanes and Isoprenoids}

The analyses of pristane, $\mathrm{n}-\mathrm{C}_{17}$, phytane, and $\mathrm{n}-\mathrm{C}_{18}$ of bitumen extracts and from coals, coaly shale, and shales (data for shale are partly from Lin et al. 1982, 1987; Kuo et al. 1987; Lin 1991; Shen and Kuo 1991; Chiu et al. 1999) are presented as the ratios of pritane/n- $\mathrm{C}_{17}$ and phytane $/ \mathrm{n}-\mathrm{C}_{18}$, which were used to examine the applicability of maturity indicators for these samples, although these parameters are commonly used as environmental indicator (Peters and Moldowan 1993). The indicators using lighter molecules are particularly relevant to the study of light oils or condensates from the Taiwan area, where heavier oil components are lacking.

(a)

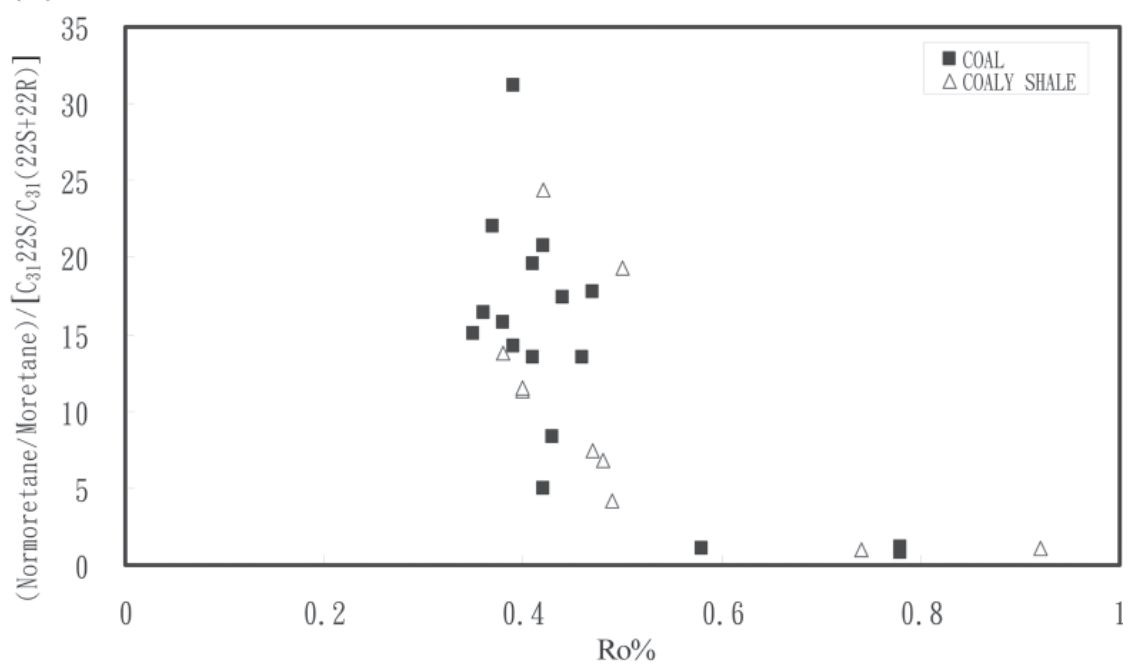

Fig. 7. The proposed parameters based on four compounds $\mathrm{C}_{31}-22 \mathrm{~S}, \mathrm{C}_{31}-22 \mathrm{R}$ homohopanes and $\mathrm{C}_{29}, \mathrm{C}_{30}$ moretanes. a) (normoretane/moretane) / [ $\mathrm{C}_{31}$ $22 \mathrm{~S} /(22 \mathrm{~S}+22 \mathrm{R})]$; b) (normoretane/norhopane) / [ $\left.\mathrm{C}_{31} 22 \mathrm{~S} /(22 \mathrm{~S}+22 \mathrm{R})\right]$. c) (moretane/hopane) / [ $\left.\mathrm{C}_{31} 22 \mathrm{~S} /(22 \mathrm{~S}+22 \mathrm{R})\right]$. The parameter ratios presented in (b) and (c) are suggested by J. N. Oung (pers. communication). 
(b)

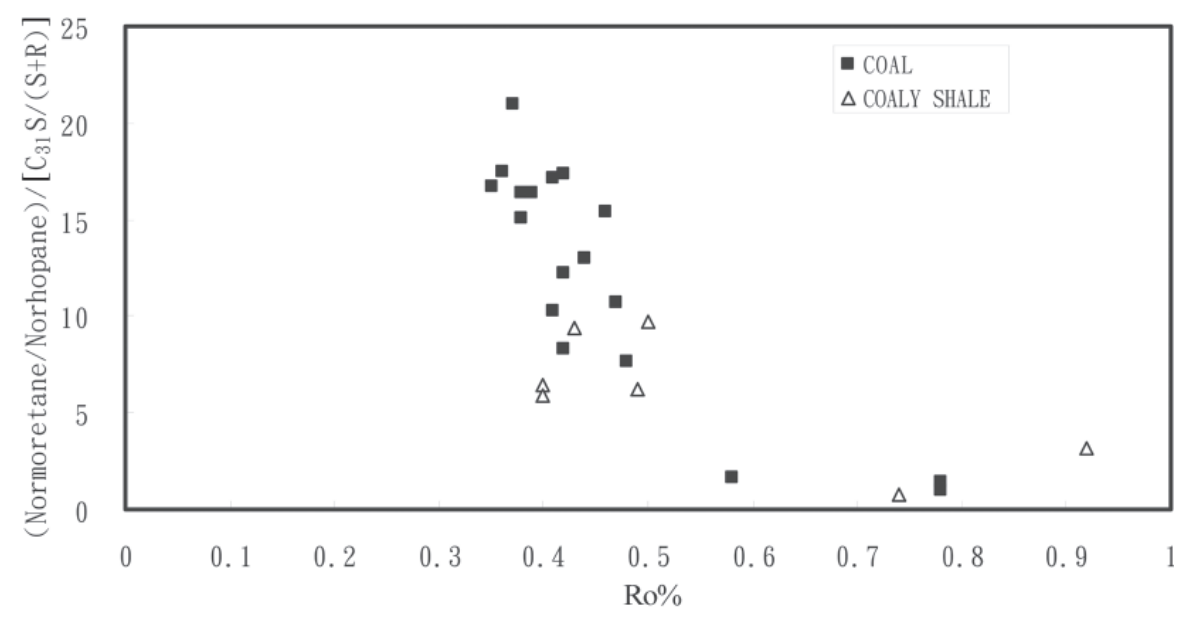

(c)

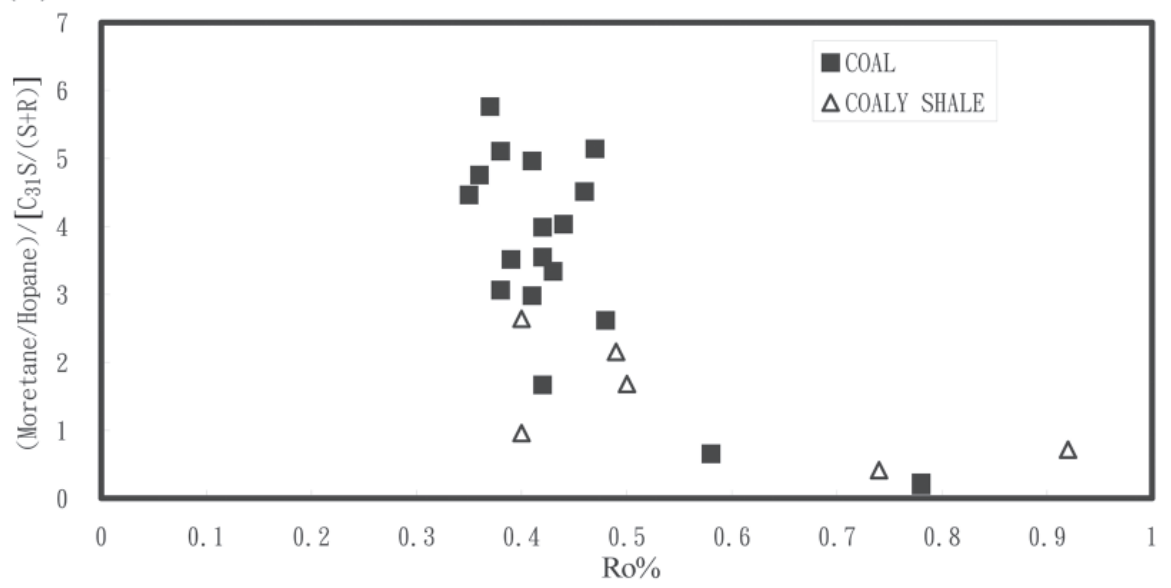

Fig. 7. (Continued)

Pistane $/ \mathrm{n}-\mathrm{C}_{17}$ ratios for all studied coals, coaly shales and shale samples reveal a trend which decreases from 8 to 0.5 with increasing VR ranging from $0.4 \%$ to $1.5 \%$ Ro (Fig. 8). The change in ratio is substantial at maturity between Ro from $0.5 \%$ to $1.0 \%$ and becomes less significant at higher maturity. The slight scatter of data may be attributed to variation in analytical errors used in different studies (Lin et al. 1982, 1987; Kuo et al. 1987; Lin 1991; Shen and Kuo 1991). Alternatively, the trend shows less scattering if individual suites of samples are considered; this indicates that other factors, e.g., depositional environment or organic sources or types, might impose influence on the ratio in addition to thermal maturity. The maturity dependence of pristane $/ \mathrm{n}-\mathrm{C}_{17}$ is consistent with that of New Zealand coals as reported in Norgate et al. (1999). 


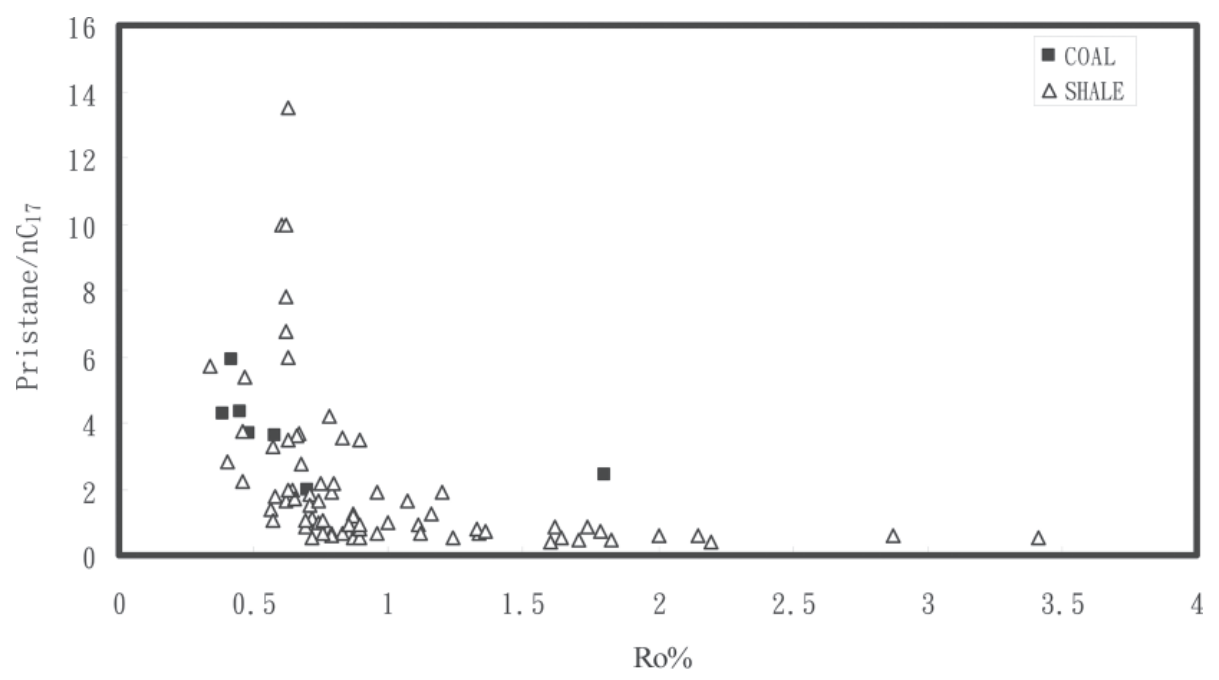

Fig. 8. The cross-plot of pristane $/ \mathrm{n}-\mathrm{C}_{17}$ ratio vs. measured vitrinite reflectance for coal, and shales from northwestern Taiwan. The ratio reaches a steady value at maturity above 1.0\% Ro. Data were partly from Lin et al. (1982, 1987), Kuo et al. (1987), Lin (1991), and Shen and Kuo (1991).

Similarly, the phytane/n- $\mathrm{C}_{18}$ ratio (Fig. 9) can be roughly correlated with Ro (\%) but the data are much more scattered, suggesting that the source influence on this ratio is probably larger than that on the pristane $/ \mathrm{n}-\mathrm{C}_{17}$ ratio. Note that the phytane $/ \mathrm{n}-\mathrm{C}_{18}$ ratio is less sensitive to maturity than that of the pristane $/ \mathrm{n}-\mathrm{C}_{17}$ ratio.

The cross-plotting of ratios of phytane $/ \mathrm{n}-\mathrm{C}_{18}$ and pristane $/ \mathrm{n}-\mathrm{C}_{17}$ from a variety of sample sources, including coals and shales, show a positive correlation although the correlation coefficient is low (Fig. 10). The positive correlation between these two ratios can be significantly improved if only a single source suite of samples, e.g., shales of Oligocene and Miocene ages from offshore Taiwan, is considered. The cluster of data at low ratios confirms that maturity indicators are insensitive for high maturity samples (Fig. 10). The plotting of pristane/phytane ratio against VR shows a similar trend for each different suite or source of samples, but a much wider scattering of data occurred if all samples were taken into account together (Fig. 11). This implies that the source of samples, age or depositional environments in addition to maturity may significantly influence the pristane/phytane ratio. It is noteworthy that the upper-bound boundary of the data shows a continuous decrease of the ratio with VR and extends to maturity beyond the oil window. This upper bound, although its implication is not clear at this stage, may be used as a potential maturity indicator if the maximum value of the ratio can be found for each maturity group of the samples. This observation is consistent with the results from New Zealand coals of a single source (Norgate et al. 1999). This significantly increases the applicability of the indicator to higher maturity than the pristane $/ n-C_{17}$ and phytane $/ n-C_{18}$ ratios. 


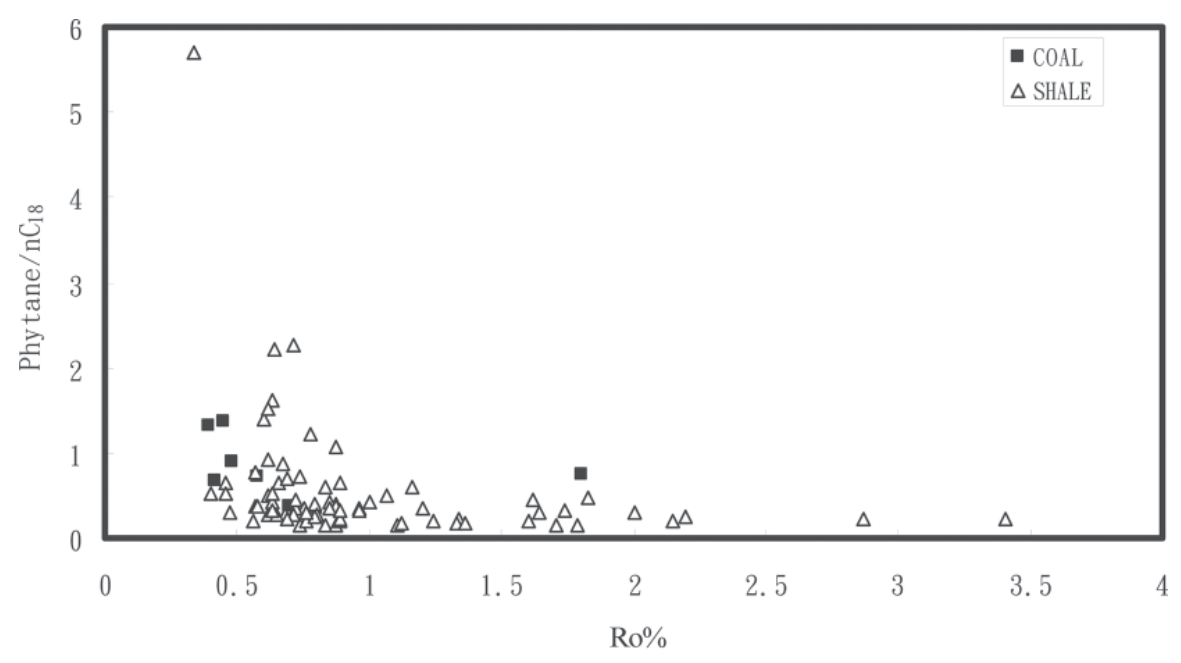

Fig. 9. The cross-plot of phytane/n- $\mathrm{C}_{18}$ ratio vs. measured vitrinite reflectance in coals, and shales. The ratios can be roughly correlated with measured vitrinite reflectance. Data were partly from Lin et al. (1982, 1987), Kuo et al. (1987), Lin (1991), Shen and Kuo (1991), and Chiu et al. (1999).

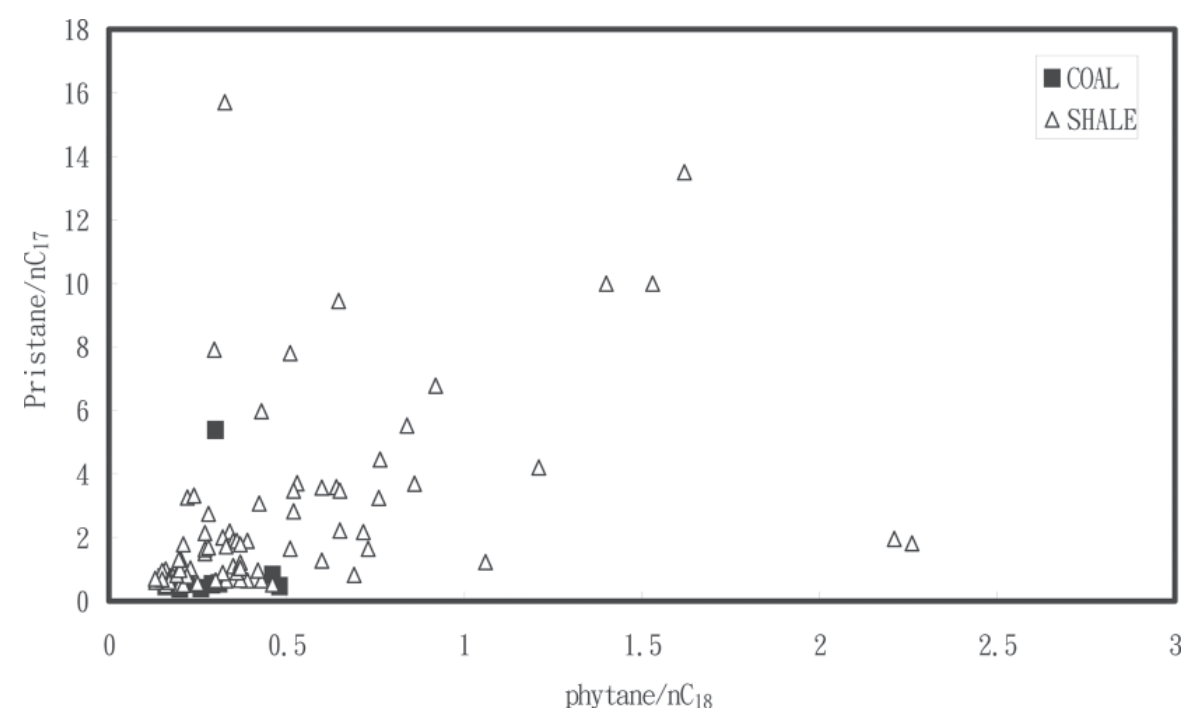

Fig. 10. The cross-plot between pristane/n- $\mathrm{C}_{17}$ and phytane $/ \mathrm{n}-\mathrm{C}_{18}$ ratios in coals, and shales. The correlation can be significantly improved if a single source of samples, e.g., shales (open triangles) of Oligocence and Miocene ages of offshore Taiwan, is considered. Data were partly from Lin et al. $(1982,1987)$, Kuo et al. (1987), Lin (1991), Shen and Kuo (1991), and Chiu et al. (1999). 


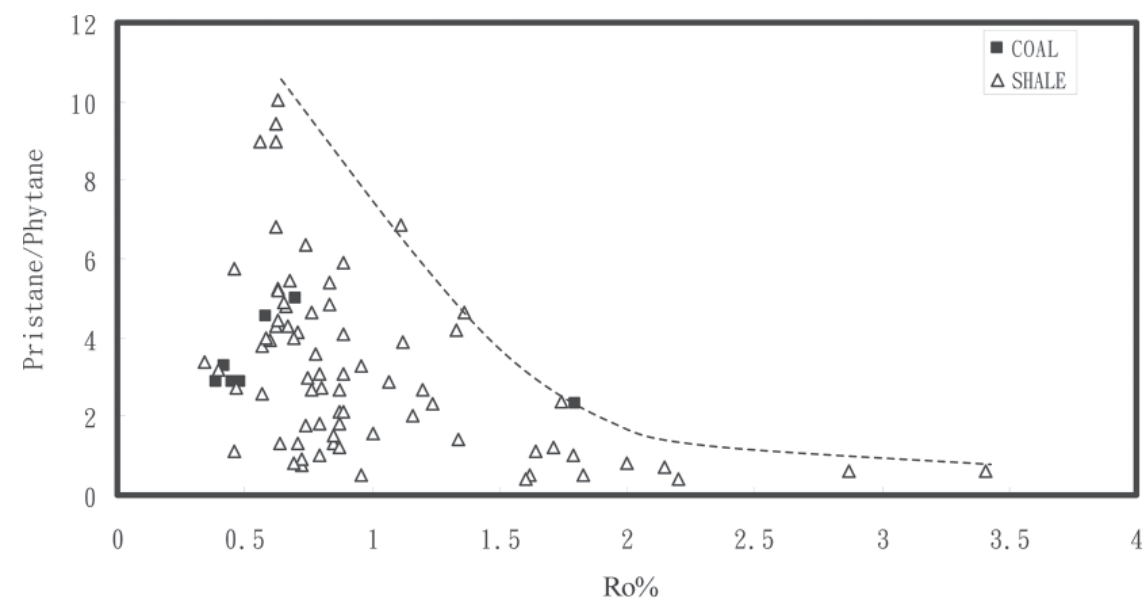

Fig. 11. The cross-plot of pristane/phytane ratio vs. measured vitrinite reflectance for coals and shales. The dashed line marks the upper-bound boundary of the data. Data were partly from Lin et al. (1982, 1987), Kuo et al. (1987), Lin (1991), Shen and Kuo (1991), and Chiu et al. (1999).

\section{CONCLUSIONS}

Several observations and conclusions can be derived according to the distribution of biomakers measured from bitumen extracts of coals, coaly shales, and shales:

(1) The change in $\mathrm{C}_{31}$ homohopane isomer ratios with vitrinite maturity of the studied coals and coaly shales is approaching a steady-state at maturity around or slightly higher than 0 . $6 \%$ Ro measured in coals. The parameter observed in the present study indicates that the onset of the main phase of petroleum generation in northwestern Taiwan takes place at maturity corresponding to VR of $0.6 \%$ Ro measured in coals or coaly shales and probably higher VR in shales. This study provides an independent assessment of vitrinite maturity in the studied area. In addition, the conventional maturity parameter using $\mathrm{C}_{31}$ homohopane isomer could be improved by newly proposed parameters, which generate trends showing a progressive increase in the parameter values with increasing VR and the attainment of steady-state at maturity similar to the $\mathrm{C}_{31}$ homohopane isomer ratio.

(2) The distribution of pristane, phytane, $n-C_{17}$ and $n-C_{18}$ in coals, coaly shales, and shales confirms the validity of previously proposed maturity indicators and indicates that other controls, e.g., depositional environment or organic sources or types in addition to thermal maturity, have significant influence on the variation in these ratios. The change in pristane/ phytane ratio, in contrast to the pristane $/ \mathrm{n}-\mathrm{C}_{17}$ ratio, appears to decrease continuously at maturity beyond the oil window up to $1.5 \%$ Ro and therefore may be applied to high maturity samples. 
Acknowledgments The geochemical analyses of samples and data processing were mostly conducted in the Geochemical Department of EDRI, Chinese Petroleum Corp. (CPC). The authors would like to thank Dr. C. L. Kuo of EDRI for general support of this work and the assistance in data acquisition. The authors would also like to thank laboratory assistants for helping the performance of analyses in the Geochemical Department of EDRI. The critical reviews and comments in early and final versions of the manuscripts by Dr. J. N. Oung of CPC significantly improve this paper. The research was supported mainly by Chinese Petroleum Corp and partly by the Earth Sciences Sections, National Sciences Council of ROC, NSC Grant 94-2116-M002-003.

\section{REFERENCES}

Abbott, G. D., G. Y. Wang, T. I. Eglinton, A. K. Home, and G. S. Petch, 1990: The kinetics of sterane biological marker release and degradation processes during the hydrous pyrolysis of vitrinite kerogen. Geochim. Cosmochim. Acta, 54, 2451-2461.

Bishop, A. N., and G. D. Abbott, 1993: The interrelationship of biological marker maturity parameters and molecular yields during contact metamorphism. Geochim. Cosmochim. Acta, 57, 3661-3668.

Bostick, N. H., and J. N. Foster, 1975: Comparison of vitrinite reflectance in coal seams and in kerogen of sandstones, shales and limestones in the same part of a sedimentary section. In: Alpern, B. (Ed.), Pétrographie de la Matière Organique des Sédiments. CNRS, Paris, $12-25$.

Chiu, J. H., S. H. Wu, and C. L. Kuo, 1999: The simulated generation potential of coal sample using hydrous pyrolysis. Petrol. Geol. Taiwan, 33, 261-274.

Chou, T. H., S. H. Wu, and L. T. Chen, 1987: Maturation parameters of biomarker in source rocks and oil (2/2). Expl. Prod. Res. Bull., 10, 161-179.

Fabianska, J. M., and K. J. Kruszewska, 2003: Relationship between petrographic and geochemical characterisation of selected South African coals. Int. J. Coal Geol., 54, 95-114.

Farrimond, P., J. C. Bevan, and A. N. Bishop, 1996: Hopanoid hydrocarbon maturation by an igneous intrusion. Org. Geochem., 25, 149-164.

Goodarzi, F., P. W. Brooks, and A. F. Embry, 1989: Regional maturity as determined by organic petrography and geochemistry of the Schei Point Group (Triassic) in the western Sverdrup Basin, Canadian Arctic Archipelago. Mar. Petrol. Geol., 6, 290-302.

Goossens, H., A. Due, J. W. de Leeuw, B. van de Graaf, and P. A. Shenck, 1988: The pristane formation index, a new molecular maturity parameter: A simple method to assess maturity by pyrolysis/evaporation-gas chromatography of unextracted samples. Geochim. Cosmochim. Acta, 52, 1189-1193.

Grantham, P. J., 1986: Sterane isomerisation and moretane/hopane ratios in crude oils derived from Tertiary source rocks. Org. Geochem., 9, 293-304.

Kuo, C. L., 1997: Application of vitrinite reflectance on hydrocarbon exploration in western Taiwan. Ph.D. Thesis, National Taiwan University, Taipei, Taiwan, ROC, 302pp. 
Kuo, C. L., J. C. Shen, J. C. Chiu, and D. C. Chen, 1987: Geochemical study of the offshore Hsinchu oil-gas field. Expl. Prod. Res. Bull., 10, 195-211.

Lin, L. H., H. H. Lin, A. H. W. Ke, and T. H. Chou, 1982: Petroleum potential of the PreMiocene Formations in the Chianan Plain, Taiwan. Petrol. Geol. Taiwan, 27, 177-197.

Lin, L. H., C. T. Chang, C. L. Kuo, and T. H. Chou, 1987: Geochemistry of hydrocarbon accumulation in Western Taiwan. Petrol. Geol. Taiwan, 31, 169-202.

Lin, L. H., 1991: Geochemical study of Tainan Basin. Expl. Prod. Res. Bull., 14, 128-146.

Lo, H. B., 1988: Photometric methods for measuring the thermal maturity on strew-mounted kerogen slides. Org. Geochem., 12, 303-307.

Lu, D. L., 1980: The technique for measuring the vitrinite reflectance of kerogen. Expl. Prod. Res. Bull., 2, 369-379.

Lu, S. T., E. Ruth, and I. R. Kaplan, 1989: Pyrolysis of kerogens in the absence and presence of montmorillonite, I. The generation, degradation and isomerization of steranes and triterpanes at 200 and $300^{\circ}$ C. Org. Geochem., 14, 491-499.

Mackenzie, A. S., R. L. Patience, J. R. Maxwell, M. Vandenbroucke, and B. Durand, 1980: Molecular parameters of maturation in the Toarcian shales, Paris Basin, France, I. Changes in the configurations of acyclic isoprenoid alkanes, steranes and triterpanes. Geochim. Cosmochim. Acta, 44, 1709-1721.

Norgate, C. M., C. J. Boreham, and A. J. Wilkins, 1999: Changes in hydrocarbon maturity indices with coal rank and type, Buller Coalfield, New Zealand. Org. Geochem., 30, 985-1010.

Oung, J. N., 1989: Geochemical studies on biomarkers in the oils from Taiwan. Petrol. Geol. Taiwan, 25, 180-210.

Oung, J. N., S. H. Wu, and F. S. Juang, 2003: Bicyclic sesquiterpanes in Tertiary coals from Taiwan. Petrol. Geol. Taiwan, 36, 53-72.

Peters, K. E., 1986: Guidelines for evaluating petroleum source rock using programmed pyrolysis. Am. Assoc. Petrol. Geol. Bull., 70, 318-329.

Peters, K. E., J. M. Moldowan, and P. Sundararaman, 1990: Effects of hydrous pyrolysis on biomarker thermal maturity parameters: Monterey phosphatic and siliceous members. Org. Geochem., 15, 249-265.

Peters, K. E., and J. M. Moldowan, 1993: The Biomarker Guide: Interpreting Molecular Fossils in Petroleum and Ancient Sediments. Prentice Hall, 352 pp.

Raymond, A. C., and D. G. Murchison, 1992: Effect of igneous activity on molecular maturation indices in different types of organic matter. Org. Geochem., 18, 725-735.

Requejo, A. G., 1994: Maturation of petroleum source rocks, II. Quantitative changes in extractable hydrocarbon content and composition associated with hydrocarbon generation. Org. Geochem., 21, 91-105.

Rullkotter, J., and R. Marzi, 1988: Natural and artificial maturation of biological markers in a Toarcian shale from northern Germany. Org. Geochem., 13, 639-645.

Seifert, W. K., and J. M. Moldowan, 1978: Applications of steranes, terpanes and monoaromatics to the maturation, migration and source of crude oils. Geochim. Cosmochim. Acta, 42, 77-95.

Seifert, W. K., and J. M. Moldowan, 1980: The effect of thermal stress on source-rock quality 
as measured by hopane stereochemistry. In: Douglas, A. G., R. J. Maxwell (Eds.), Advances in Organic Geochemistry 1979, Pergamon Press, Oxford, 229-237.

Shen, J. C., and C. L. Kuo, 1991: Relationship between coal and hydrocarbon in Hsinchu and Miaoli areas. Expl. Prod. Res. Bull., 14, 277-295.

van Graas, G., J. W. Leeuw, P. A. Schenk, and J. Haverkamp, 1981: Kerogen of Toarcian shales of the Paris Basin: A study of its maturation by flash pyrolysis technique. Geochim. Cosmochim. Acta, 45, 2465-2474.

Waples, D. W., and T. Machihara, 1991: Biomarkers for Geologist. AAPG Bull., 91 pp.

Wu, S. H., L. T. Chen, and J. H. Chiu, 1986: Maturation parameters of biomarker in source rocks and oil (1/2). Expl. Prod. Res. Bull., 9, 192-215.

Shen, J. C. W. L. Huang, 2007: Biomarker distributions as maturity indicators in coals, coaly shales, and shales from Taiwan. Terr. Atmos. Ocean. Sci., 18, 739-755, doi: 10.3319/ TAO.2007.18.4.739(TT). 